\title{
SKALA USAHA DAN DIVERSIFIKASI PRODUK TAHU DI KABUPATEN OKU TIMUR
}

\author{
(Serly Novita Sari)
}

\begin{abstract}
The purpose of this study is to: (1) To know the scale of the business of tofu industry in East OKU Regency, (2) To know the diversification of tofu products produced by tofu industry in East OKU Regency, (3) Calculate the amount of expenses incurred, acceptance and Profit gained from the know-making business in East OKU Regency. This research will be conducted in OKU Timur Regency. Determining the location is done purposively with consideration that in OKU Timur Regency is not soybean production center, but there are many business units of tofu manufacture consisting of tofu chinese, tofu half cooked and fried tofu. The study was conducted in July 2014. The study found that the $R$ / C ratio of tofu industry ratio with soybean requirement $>1,000 \mathrm{Kg}$ per month was 1.23. The $R / C$ ratio of tofu industry ratio with soybean requirement of 500-1000 Kg per month is 1.15. The $R / C$ ratio of tofu industry ratio with soybean requirement $<500 \mathrm{Kg}$ per month is 1.17. Based on the calculation of $R / C$ ratio, the industry ratio of more than $1(R / C>1)$ indicates that the know-making business in OKU Timur Regency is profitable. Know-how with soybean requirement> 1,000 Kg per month has the greatest $R$ / C ratio of 1.23 This shows the business of making tofu with soybean requirement> $1000 \mathrm{Kg}$ per month is more profitable than other tofu industry.
\end{abstract}

Key Words : Agro industry, Product Diversification, Value-added.

\section{PENDAHULUAN}

\section{A. Latar Belakang}

Agroindustri merupakan suatu bentuk kegiatan atau aktifitas yang mengolah bahan baku yang berasal dari tanaman maupun hewan. Agroindustri memiliki peranan yang sangat penting dalam pembangunan pertanian. Hal ini dapat dilihat dari kontribusinya dalam hal meningkatkan pendapatan pelaku agribisnis, menyerap tenaga kerja, meningkatkan perolehan devisa, dan mendorong tumbuhnya industri lain.

Salah satu agroindustri yang cukup potensial di Indonesia untuk dikembangkan adalah industri tahu. Tahu merupakan salah satu bahan makanan pokok yang termasuk dalam empat sehat lima sempurna. Tahu juga merupakan makanan yang mengandung banyak gizi dan mudah diproduksi. Untuk memproduksi tahu bahan-bahan yang dibutuhkan hanya berupa kacang kedelai, sehingga saat ini dapat ditemukan banyak pabrik pembuat tahu baik dalam bentuk usaha kecil maupun usaha menengah yang masih menggunakan cara konvensional (Lihannoor, 2010).

Umumnya tahu digunakan sebagai laukpauk dan sebagai makanan tambahan atau jajanan. Potensi tahu dalam meningkatkan kesehatan dan harganya relatif murah memberikan alternatif pilihan dalam pengadaan makanan bergizi yang dapat dijangkau oleh segala lapisan masyarakat. Pada dasarnya tahu terdiri dari protein dan air. Tahu terbukti mengandung $65 \%$ protein yang dapat dimanfaatkan tubuh serta memiliki daya cerna yang tinggi, yakni sebesar $85 \%$ - 98\%. Tahu mengandung sekitar $80 \%$ asam lemak tak jenuh, sehingga tidak mengandung kolestrol. Karena kandungan hidrat arang dan kalorinya rendah, tahu sangat baik menjadi salah satu menu diet rendah kalori.

Menurut Sarwono dan Saragih (2003), tahu mengandung zat gizi yang tinggi dan berdasarkan kandungan zat gizi pada tahu tersebut menunjukkan bahwa industri tahu mempunyai prospek yang baik untuk dikembangkan. Adapun komposisi zat gizi dalam $100 \mathrm{~g}$ tahu segar disajikan pada tabel berikut ini.

Tabel 1. Komposisi Nilai Gizi Pada 100g Tahu Segar.

\begin{tabular}{clc}
\hline No. & \multicolumn{1}{c}{ Komposisi } & Jumlah \\
\hline 1. & Energi (kalori) & 6 \\
2. & Air (g) & 86,7 \\
3. & Protein (g) & 7,9 \\
4. & Lemak (g) & 4,1 \\
5. & Karbohidrat (g) & 0,4 \\
6. & Kalsium (mg) & 150 \\
7. & Besi (mg) & 0,2 \\
8. & Vitamin B1(mg) & 0,04 \\
9. & Vitamin B2 (mg) & 0,02
\end{tabular}

Sumber: Sarwono dan Saragih, 2003.

Industri tahu merupakan industri kecil yang mampu menyerap sejumlah besar tenaga kerja baik yang terkait langsung dalam proses produksi maupun yang terkait dengan perdagangan bahan yang merupakan masukan maupun produk hasil olahannya. Prospek industri tahu sangat baik dimana pertumbuhan permintaan tahu diperkirakan mencapai 4 persen per tahun (Solahudin, 1998). 
Industri tahu memiliki peranan yang cukup besar didala usaha pemerataan kesempatan kerja, kesempatan berusah dan peningkatkan pendapatan. Menurut Ambarwati (1994), industri tahu pada umumnya dikelola dalam bentuk industri rumah tangga, sehingga perkembangannya selalu dihadapkan dengan permasalahan yang menyangkut bahan baku yaitu kedelai, ketersediaan dan kualitas faktor produksi, tingkat keuntungan, pemasaran serta permodalan. Pendapatan para pengrajin tahu sangat tergantung dari penjualan dan biaya yang dikeluarkan.

Industri tahu adalah jenis usaha yang umumnya merupakan industri kecil dan menengah (UKM) dengan investasi tidak terlalu besar dengan jumlah tenaga kerja yang relatif sedikit. Namun industri tahu telah banyak menjadi sumber pendapatan dan memenuhi kebutuhan produk pangan bergizi tinggi dengan harga yang terjangkau bagi sebagian besar masyarakat Indonesia. Seiring dengan pertambahan jumlah penduduk nasional yang terus meningkat, menunjukkan bahwa potensi pasar produk tahu akan semakin besar dan merupakan peluang untuk mengembangkan agribisnis tahu.

Usaha pembuatan tahu di Kabupaten OKU Timur merupakan industri skala rumah tangga yang pada awal pendiriannya terdorong motivasi untuk berusaha sendiri. Sebagian besar tenaga kerja dalam usaha ini berasal dari dalam keluarga. Walaupun skalanya masih kecil dan bersifat tradisional, tetapi usaha pembuatan tahu dapat dijadikan sumber pendapatan bagi masyarakat dan dapat bertahan diantara usaha lain yang lebih besar dan di dalam gejolak harga kedelai yang cenderung tinggi.

Banyaknya unit usaha pembuatan tahu skala rumah tangga di Kabupaten OKU Timur menunjukkan bahwa usaha pembuatan tahu skala rumah tangga yang sudah diusahakan selama lebih dari sepuluh tahun dapat memberikan keuntungan karena mampu menyerap tenaga kerja dan bertahan di tengah persaingan serta gejolak kenaikan harga kedelai. Usaha pembuatan tahu ini mampu menggerakkan perekonomian masyarakat setempat, meningkatkan pendapatan rumah tangga dan kesejahteraan hidup pengrajin tahu, akan tetapi belum diketahui sejauh mana keberhasilan yang dicapai.

\section{B. Rumusan Masalah}

1. Bagaimana skala usaha industri tahu di Kabupaten OKU Timur.

2. Bagaimana analisis diversifikasi produk tahu di Kabupaten OKU Timur.
3. Berapa besar biaya yang dikeluarkan, penerimaan dan keuntungan yang diperoleh dari usaha pembuatan tahu di Kabupaten OKU Timur.

\section{Tujuan dan Kegunaan}

1. Untuk mengetahui skala usaha industri pembuatan tahu di Kabupaten OKU Timur.

2. Untuk mengetahui diversifikasi produk tahu yang dihasilkan industri tahu di Kabupaten OKU Timur.

3. Menghitung besarnya biaya yang dikeluarkan, penerimaan dan keuntungan yang diperoleh dari usaha pembuatan tahu di Kabupaten OKU Timur.

\section{Model Pendekatan}

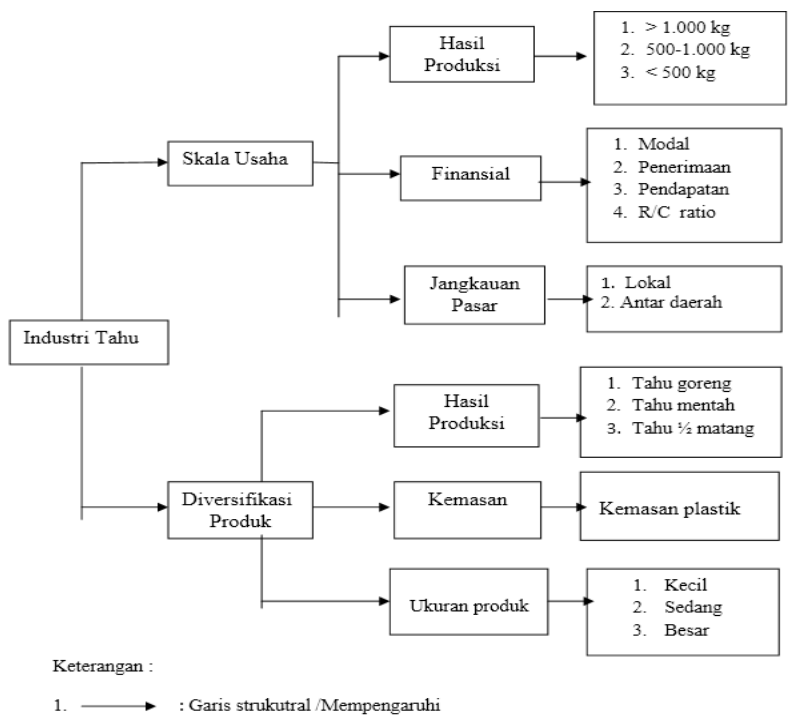

Gambar 1. Model pendekatan penelitian secara diagramatik

\section{METODOLOGI PENELITIAN}

\section{A. Tempat dan Waktu}

Penelitian ini akan dilaksanakan di Kabupaten OKU Timur. Penentuan lokasi dilakukan secara sengaja (purposive) dengan pertimbangan bahwa di Kabupaten OKU Timur bukanlah sentra produksi kedelai, tetapi banyak terdapat unit usaha pembuatan tahu yang terdiri dari tahu cina, tahu setengah matang dan tahu goreng. Penelitian lapangan telah dilaksanakan pada Bulan Juli 2014.

\section{B. Metode Penelitian}

Metode yang akan dilakukan dalam penelitian ini adalah metode survei terhadap pengusaha industri pembuatan tahu yang terdapat di Kabupaten OKU Timur. Metode survei adalah 
penelitian yang mengambil sampel dari suatu populasi dan menggunakan panduan kuisioner sebagai alat pengumpul data yang pokok.

\section{Metode Penarikan Contoh}

Penelitian ini dilakukan berdasarkan sampel daerah dengan meminta keterangan dari Disperindag Kab OKU Timur dan BP3K, manakah kecamatan di Kab OKU Timur yang memiliki industri tahu skala rumah tangga terbanyak. Terdapat 3 kecamatan yang memiliki industri tahu terbanyak dan yang tercatat di Disperindag Kabupaten OKU Timur yaitu Kecamatan Belitang Mulya, Kecamatan Buay Madang Timur dan Kecamatan Buay Madang. Adapun jumlah unit usaha pembuatan tahu di Kabupaten OKU Timur disajikan pada Tabel 2 berikut ini.

Tabel 2. Sebaran Pengrajin Tahu di Kabupaten OKU Timur.

\begin{tabular}{clc}
\hline No & Kecamatan & Jumlah Industri Tahu \\
\hline 1. & Belitang Mulya & 21 \\
2. & Buay Madang Timur & 11 \\
3. & Buay Madang & 17 \\
\hline & Jumlah Pengusaha & 49
\end{tabular}

Sumber: Data Primer, 2014.

Pemilihan sampel dilakukan secara simple random sampling (sampel acak sederhana) yaitu semua individu dalam populasi diberikan kesempatan untuk dipilih menjadi anggota sampel. Dalam penelitian ini jumlah sampel yang diambil sebanyak 9 industri tahu yang terdiri dari 3 industri tahu goreng, 3 industri tahu putih (Cina) mentah dan 3 industri tahu cina setengah matang. Pengambilan sampel dilakukan secara proporsional yang diklasifikasikan dalam 3 skala usaha yaitu 3 industri tahu yang kapasitas produksi $>1.000 \mathrm{Kg} /$ Bulan, 3 industri tahu yang kapasitas produksi $500 \mathrm{~s} / \mathrm{d} 1.000 \mathrm{Kg} / \mathrm{Bulan}$ dan 3 industri tahu dengan kapasitas produksi $<500$ $\mathrm{Kg} /$ Bulan.

Tabel 3. Jumlah Sampel dan Kapasitas Produksi Kedelai Industri Pembuatan Tahu Skala Rumah Tangga di Kabupaten OKU Timur.

\begin{tabular}{lccccc}
\hline No & $\begin{array}{c}\text { Kebutuhan Kedelai } \\
(\mathrm{Kg} \text { Bulan })\end{array}$ & $\begin{array}{c}\text { Jumlah Unit } \\
\text { Usaha }\end{array}$ & $\begin{array}{c}\text { Persentase } \\
(\%)\end{array}$ & $\begin{array}{c}\text { Sampel } \\
(\text { Unit })\end{array}$ & $\begin{array}{c}\text { Persentase } \\
(\%)\end{array}$ \\
\hline 1. & $>1.000 \mathrm{Kg}$ & 22 & 44,9 & 3 & 13,6 \\
2. & $500<1.000 \mathrm{Kg}$ & 12 & 24,5 & 3 & 25 \\
3. & $<500 \mathrm{Kg}$ & 15 & 30,6 & 3 & 20 \\
\hline & Jumlah & 49 & $100 \%$ & 9 & $58,6 \%$ \\
\hline
\end{tabular}

Sumber: Data Primer, 2014.
Dalam penelitian ini dianalisa adalah tingkatan skala usaha dan diversifikasi produk tahu di Kabupaten OKU Timur. Skala Usaha menggambarkan akan kebutuhan bahan baku kedelai yang dibutuhkan dalam proses produksi selama 1 bulan. Adapun diversifikasi produk tahu menggambarkan keanekaragaman produk yang dihasilkan pada setiap skala usaha.

Untuk menguji hipotesis 1 dan 2 bahwa terdapat diversifikasi produk tahu yang dihasilkan dan bahwa industri tahu di Kabupaten OKU Timur termasuk skala usaha mikro maka digunakan metode dan analisa deskriptif dengan menggunakan data primer yang diperoleh dari hasil wawancara dengan pengrajin tahu di daerah penelitian. Data yang diperoleh dari lapangan diolah secara tabulasi lalu di analisa desktritaif yaitu metode penelitian yang menggunakan angka yang kemudian diolah, dianalisis dan ditarik kesimpulan yang menggambarkan objek yang diteliti.

\section{Metode Pengolahan Data}

Data yang diperoleh dari lapangan diolah secara tabulasi lalu di analisa desktritif yaitu metode penelitian yang menggunakan angka yang kemudian diolah, dianalisis dan ditarik kesimpulan yang menggambarkan objek yang diteliti. Untuk menguji hipotesis 1 bahwa usaha pembuatan tahu skala rumah tangga di Kabupaten OKU Timur cukup menguntungkan maka dapat digunakan rumus :

a) Untuk mengetahui biaya produksi (Soekartawi, 2002), dengan rumus:

$\mathrm{TC}=\mathrm{FC}+\mathrm{VC}$

Dimana :

$\mathrm{TC}=$ Total Cost/Biaya Produksi (Rp/PP)

$\mathrm{FC}=$ Fixed Cost/Biaya Tetap (Rp/PP)

$\mathrm{VC}=$ Variabel Cost/Biaya Variabel $(\mathrm{Rp} / \mathrm{PP})$

b) Untuk mengetahui penerimaan, digunakan rumus :

$\mathrm{TR}=\mathrm{Y} \times \mathrm{P}$

Dimana :

$\mathrm{TR}=$ Total Revenues $/$ Penerimaan $(\mathrm{Rp} / \mathrm{PP})$

$\mathrm{Y}=$ Yield/Hasil Produksi (Potong/PP)

$\mathrm{P}=$ Price/Harga Jual (Rp/Potong)

c) Untuk menghitung pendapatan, digunakan rumus :

$\mathrm{I}=\mathrm{TR}-\mathrm{TC}$

Dimana :

$\mathrm{I}=$ Income/Pendapatan $(\mathrm{Rp} / \mathrm{PP})$

$\mathrm{TR}=$ Total Revenue $/$ Penerimaan $(\mathrm{Rp} / \mathrm{PP})$

$\mathrm{TC}=$ Total Cost $/$ Total Biaya Produksi ( $\mathrm{Rp} / \mathrm{PP})$

d) $\mathrm{R} / \mathrm{C}$ ratio dihitung dengan menggunakan rumus : 
$\mathrm{R} / \mathrm{C}$ ratio $=\frac{\mathrm{TR}}{\mathrm{TC}}$

Dimana :

$\mathrm{R} / \mathrm{C}=$ Revenues per cost

$\mathrm{TR}=$ Total Revenues $/$ Penerimaan $(\mathrm{Rp} / \mathrm{PP})$

$\mathrm{TC}=$ Total Cost $/$ Biaya Total $(\mathrm{Rp} / \mathrm{PP})$

Dengan kriteria :

- R/C Ratio > 1 Berarti usaha menguntungkan.

- R/C Ratio = 1 Berarti usah,tidak untung dan tidak rugi (impas).

- R/C Ratio < 1 Berarti usaha tidak menguntungkan (rugi).

Untuk menguji hipotesis 2 dan 3 bahwa terdapat diversifikasi produk tahu yang dihasilkan dan bahwa industri tahu di Kabupaten OKU Timur termasuk skala usaha mikro maka digunakan metode dan analisa deskriptif dengan menggunakan data primer yang diperoleh dari hasil wawancara dengan pengrajin tahu di daerah penelitian.

\section{HASIL DAN PEMBAHASAN}

\section{A. Karakteristik Sampel (Responden)}

Jumlah sampel usaha industri tahu dalam penelitian ini adalah sebanyak 9 responden perajin industri tahu di Kabupaten OKU Timur yang terdiri dari 3 responden industri tahu dengan kebutuhan kedelai $>1.000 \mathrm{~kg} / \mathrm{bulan}, 3$ responden industri tahu dengan kebutuhan kedelai antara 500 sampai $1.000 \mathrm{~kg}$ per bulan dan 3 responden industri tahu dengan kebutuhan kedelai $>500 \mathrm{~kg}$ per bulan.

Tabel 4. Identitas Responden Industri Tahu di Kabupaten OKU Timur Kebutuhan Kedelai $>1.000 \mathrm{Kg} /$ Bulan.

\begin{tabular}{|c|c|c|c|c|c|c|c|}
\hline No & Nama & $\begin{array}{l}\text { Umur } \\
\text { (Thn) }\end{array}$ & $\begin{array}{l}\text { Lama } \\
\text { Usaha } \\
\text { (Thn) }\end{array}$ & $\begin{array}{l}\text { Luas } \\
\text { Lahan } \\
\left(M^{2}\right)\end{array}$ & $\begin{array}{c}\text { Kebutuhan } \\
\text { Kedelai } \\
\text { (KgProses) }\end{array}$ & $\begin{array}{c}\text { Kebutuhan } \\
\text { Kedelai } \\
(\mathrm{Kg} B \mathrm{Bh})\end{array}$ & $\begin{array}{c}\text { Pendidikan } \\
\text { Formal }\end{array}$ \\
\hline 1 & Jumingan & 50 & 21 & 100 & 100 & 3.000 & $S D$ \\
\hline 2 & Sujarno & 48 & 20 & 100 & 60 & 1.800 & SD \\
\hline 3 & Solikm & 40 & 13 & 100 & 40 & 1.200 & SD \\
\hline Jumlah & & 138 & 54 & 300 & 200 & 6.000 & \\
\hline Rata-rata & & 46 & 18 & 100 & 67 & 2.000 & \\
\hline
\end{tabular}

Sumber: Data Primer, 2014.

Tabel 5. Identitas Responden Industri Tahu di Kabupaten OKU Timur Kebutuhan Kedelai $500 \mathrm{~s} / \mathrm{d} 1.000 \mathrm{Kg} / \mathrm{Bulan}$.

\begin{tabular}{ccrrrcrc}
\hline No & Nama & Umur & $\begin{array}{c}\text { Lama } \\
\text { Usaha } \\
\end{array}$ & $\begin{array}{c}\text { Luas } \\
\text { Lahan } \\
(\text { Thn) }\end{array}$ & $\begin{array}{c}\text { Kebunhan } \\
\text { Kedelai } \\
\left(\mathrm{M}^{2}\right)\end{array}$ & $\begin{array}{c}\text { Kebutuhan } \\
\text { Kedelai } \\
\text { (KgProses) }\end{array}$ & $\begin{array}{c}\text { Pendidikan } \\
\text { Formal }\end{array}$ \\
\hline 1 & Muhammad & 42 & 15 & 80 & 25 & 750 & SD \\
2 & Gepeng & 40 & 15 & 100 & 30 & 900 & SMP \\
3 & Azz & 37 & 15 & 100 & 20 & 600 & SD \\
\hline Jumlah & 119 & 45 & 280 & 75 & 2.250 & \\
Rata-rata & 40 & 15 & 93 & 25 & 750 & \\
\hline
\end{tabular}

Sumber: Data Primer, 2014.
Tabel 6. Identitas Responden Industri Tahu di Kabupaten OKU Timur Kebutuhan Kedelai $<500 \mathrm{Kg} /$ Bulan.

\begin{tabular}{crrrrrrc}
\hline No & Nama & Umur & $\begin{array}{c}\text { Lama } \\
\text { Usaha } \\
(\mathrm{Thn})\end{array}$ & $\begin{array}{c}\text { Luas } \\
\text { Lahan } \\
\left(\mathrm{M}^{2}\right)\end{array}$ & $\begin{array}{r}\text { Kedelai } \\
\text { Kg/Proses }\end{array}$ & $\begin{array}{r}\text { Kedelai } \\
(\mathrm{Kg} / \mathrm{Bm})\end{array}$ & $\begin{array}{c}\text { Pendidikan } \\
\text { Formal }\end{array}$ \\
\hline 1 & Mukti & 34 & 12 & 60 & 10 & 300 & SMP \\
2 & Markum & 45 & 13 & 100 & 15 & 450 & SD \\
3 & Wakiran & 32 & 15 & 90 & 15 & 450 & SMA \\
\hline Jumlah & 111 & 40 & 250 & 40 & 1.200 & \\
Rata-rata & 37 & 13 & 83 & 13 & 400 & \\
\hline
\end{tabular}

Sumber: Data Primer, 2014.

Kebutuhan kedelai yang digunakan oleh responden industri tahu di Kabupaten OKU Timur dengan kebutuhan kedelai > $1.000 \mathrm{~kg}$ (tabel 4) adalah rata-rata sebanyak $67 \mathrm{Kg}$ dalam satu kali proses produksi atau sebanyak $2.000 \mathrm{Kg}$ per bulan. Rata-rata kebutuhan kedelai industri tahu dengan kebutuhan kedelai 500 - $1.000 \mathrm{~kg}$ per bulan (tabel 5) adalah rata-rata sebanyak $25 \mathrm{Kg}$ dalam satu kali proses produksi atau sebanyak $750 \mathrm{Kg}$ per bulan sedangkan industri tahu dengan kebutuhan kedelai < $500 \mathrm{~kg}$ (tabel 6) adalah sebanyak $13 \mathrm{Kg}$ per hari atau sebanyak $400 \mathrm{Kg}$ per bulan. Adapun kedelai yang digunakan oleh responden adalah kedelai impor. Alasan responden lebih memilih menggunakan kedelai impor karena mutunya lebih bagus dan selalu tersedia dibandingkan dengan kedelai lokal.

\section{B. Diversifikasi Produk Tahu}

Diversifikasi produk tahu yang dihasilkan oleh responden industri tahu di Kabupaten OKU Timur meliputi tahu goreng, tahu cina mentah dan tahu cina $1 / 2$ matang. Setiap responden industri tahu dalam penelitian menghasilkan 3 macam produk tahu yaitu tahu goreng, tahu cina mentah dan tahu cina $1 / 2$ matang. Adapun hasil deskriptif mengenai diversifikasi produk tahu masingmasing responden adalah sebagai berikut :

\section{Industri Tahu dengan Kebutuhan Kedelai > $1.000 \mathrm{Kg} /$ Bulan.}

a. Jumingan (Tabel 7)

\begin{tabular}{llrrr}
\hline \multirow{2}{*}{ No } & \multicolumn{3}{c}{ Uraian } & Produk Tahu \\
\cline { 2 - 5 } & Tahu Goreng & Tahu Cina & Tahu 1/2 Matang \\
\hline 1. Jumlah Tahu (Ptng/PP) & 3.000 & 2.400 & 900 \\
2. & Ukuran Tahu $\left(\mathrm{Cm}^{3}\right)$ & $4 \times 4 \times 2$ & $6 \times 6 \times 2$ & $6 \times 6 \times 2$ \\
3. & Kemasan & Plastik & Plastik & Plastik \\
4. & Harga (Rp/Potong) & 200 & 450 & 500 \\
5. & Penerimaan (Rp/proses) & 600.000 & 1.080 .000 & 450.000 \\
\hline
\end{tabular}

Sumber: Data Primer, 2014.

Berdasarkan tabel di atas dapat diketahui bahwa jumlah tahu yang dihasilkan oleh Responden 1 (Bapak Jumingan) dalam satu kali proses produksi adalah : tahu goreng sebanyak 3.000 potong dengan ukuran $4 \times 4 \times 2 \mathrm{~cm}$ dengan 
harga jual $\mathrm{Rp}$ 200/potong sehingga diperoleh penerimaan sebesar $\mathrm{Rp}$ 600.000. Tahu Cina mentah sebanyak 2.400 potong dengan ukuran $6 \mathrm{x}$ $6 \times 2 \mathrm{~cm}$ dengan harga jual Rp 450/potong sehingga diperoleh penerimaan sebesar $\mathrm{Rp}$ 1.080.000. Tahu cina $1 / 2$ matang sebanyak 900 potong dengan ukuran $6 \times 6 \times 2 \mathrm{~cm}$ dan harga jual $\mathrm{Rp}$ 500/potong sehingga diperoleh penerimaan sebesar Rp 450.000.

b. Sujarno (Tabel 8)

\begin{tabular}{lrrrr}
\hline \multirow{2}{*}{ No } & \multicolumn{3}{c}{ Uraian } & Produk Tahu \\
\cline { 3 - 5 } & Tahu Goreng & Tahu Cina & Tahu 1/2 Matang \\
\hline 1. Jumlah Tahu (Ptng/PP) & 2.000 & 1.000 & 1.000 \\
2. Ukuran Tahu (Cm $\left.{ }^{3}\right)$ & $5 \times 3 \times 2,5$ & $6 \times 5 \times 2,5$ & $6 \times 5 \times 2,5$ \\
3. Kemasan & Plastik & Plastik & Plastik \\
4. Harga (Rp/Potong) & 200 & 450 & 500 \\
5. Penerimaan (Rp/proses) & 400.000 & 450.000 & 500.000
\end{tabular}

Sumber: Data Primer, 2014.

Berdasarkan tabel di atas dapat diketahui bahwa jumlah tahu yang dihasilkan oleh Responden 2 (Bapak Sujarno) dalam satu kali proses produksi adalah : tahu goreng sebanyak 2.000 potong dengan ukuran $5 \times 3 \times 2,5 \mathrm{~cm}$ dengan harga jual Rp 200/potong sehingga diperoleh penerimaan sebesar Rp 400.000. Tahu Cina mentah sebanyak 1.000 potong dengan ukuran $6 \times 5 \times 2,5 \mathrm{~cm}$ dengan harga jual Rp 450/potong sehingga diperoleh penerimaan sebesar $\mathrm{Rp}$ 450.000. Tahu cina $1 / 2$ matang sebanyak 1.000 potong dengan ukuran $6 \times 5 \times 2,5$ $\mathrm{cm}$ dan harga jual Rp 500/potong sehingga diperoleh penerimaan sebesar Rp 500.000.

c. Solikin (Tabel 9)

\begin{tabular}{|c|c|c|c|c|}
\hline \multirow{2}{*}{ No } & \multirow{2}{*}{ Uraian } & \multicolumn{3}{|c|}{ Produk Tahu } \\
\hline & & Tahu Goreng & Tahu Cina & Tahu $1 / 2$ Matang \\
\hline 1. & Jumlah Tahu (Ptng/PP) & 1.800 & 950 & 500 \\
\hline 2. & Ukuran Tahu ( $\left.\mathrm{Cm}^{3}\right)$ & $4 \times 4 \times 2$ & $6 \times 6 \times 2$ & $6 \times 6 \times 2$ \\
\hline 3. & Kemasan & Plastik & Plastik & Plastik \\
\hline 4. & Harga (Rp/Potong) & 200 & 450 & 500 \\
\hline & Penerimaan (Rp/proses) & 360.000 & 427.500 & 250.000 \\
\hline
\end{tabular}

Sumber: Data Primer, 2014.

Berdasarkan tabel di atas dapat diketahui bahwa jumlah tahu yang dihasilkan oleh Responden 3 (Bapak Solikin) dalam satu kali proses produksi adalah : tahu goreng sebanyak 1.800 potong dengan ukuran $4 \times 4 \times 2,5 \mathrm{~cm}$ dengan harga jual Rp 200/potong sehingga diperoleh penerimaan sebesar Rp 360.000. Tahu Cina mentah sebanyak 950 potong dengan ukuran $6 \times 6 \times 2 \mathrm{~cm}$ dengan harga jual Rp 450/potong sehingga diperoleh penerimaan sebesar $\mathrm{Rp}$ 427.500. Tahu cina $1 / 2$ matang sebanyak 1.000 potong dengan ukuran $6 \times 6 \times 2 \mathrm{~cm}$ dan harga jual $\mathrm{Rp}$ 500/potong sehingga diperoleh penerimaan sebesar Rp 250.000.

\section{Industri Tahu dengan Kebutuhan Kedelai} 500 - $1.000 \mathrm{Kg} /$ Bulan.

a. Muhammad (Tabel 10)

\begin{tabular}{|c|c|c|c|c|}
\hline \multirow{2}{*}{ No } & \multirow{2}{*}{ Uraian } & \multicolumn{3}{|c|}{ Produk Tahu } \\
\hline & & Tahu Goreng & Tahu Cina & Tahu $1 / 2$ Matang \\
\hline 1. & Jumlah Tahu (Ptng/PP) & 1.100 & 600 & 250 \\
\hline 2. & Ukuran Tahu $\left(\mathrm{Cm}^{3}\right)$ & $4 \times 4 \times 2$ & $6 \times 5 \times 2,5$ & $6 \times 5 \times 2,5$ \\
\hline 3. & Kemasan & Plastik & Plastik & Plastik \\
\hline 4. & Harga (Rp/Potong) & 200 & 500 & 500 \\
\hline 5. & Penerimaan (Rp/proses) & 220.000 & 300.000 & 125.000 \\
\hline
\end{tabular}

Sumber: Data Primer, 2014.

Berdasarkan tabel di atas dapat diketahui bahwa jumlah tahu yang dihasilkan oleh Responden 4 (Bapak Muhammad) dalam satu kali proses produksi adalah : tahu goreng sebanyak 1.100 potong dengan ukuran $4 \times 4 \times 2 \mathrm{~cm}$ dengan harga jual Rp 200/potong sehingga diperoleh penerimaan sebesar Rp 220.000. Tahu Cina mentah sebanyak 600 potong dengan ukuran $6 \times 5$ x 2,5 cm dengan harga jual Rp 500/potong sehingga diperoleh penerimaan sebesar $\mathrm{Rp}$ 300.000. Tahu cina $1 / 2$ matang sebanyak 250 potong dengan ukuran $6 \times 5 \times 2,5 \mathrm{~cm}$ dan harga jual $\mathrm{Rp}$ 500/potong sehingga diperoleh penerimaan sebesar Rp 125.000.

b. Gepeng (Tabel 11)

\begin{tabular}{|c|c|c|c|c|}
\hline \multirow{2}{*}{ No } & \multirow{2}{*}{ Uraian } & \multicolumn{3}{|c|}{ Produk Tahu } \\
\hline & & Tahu Goreng & Tahu Cina & Tahu $1 / 2$ Matang \\
\hline 1. & Jumlah Tahu (Ptng PP) & 1.500 & 1.500 & 200 \\
\hline 2. & Ukuran Tahu $\left(\mathrm{Cm}^{3}\right)$ & $4 \times 4 \times 2$ & $4 \times 4 \times 2$ & $6 \times 6 \times 2$ \\
\hline 3. & Kemasan & Plastik & Plastik & Plastik \\
\hline 4. & Harga (Rp/Potong) & 200 & 200 & 500 \\
\hline 5. & Penerimaan (Rpproses) & 300.000 & 300.000 & 100.000 \\
\hline
\end{tabular}

Sumber: Data Primer, 2014.

Berdasarkan tabel di atas dapat diketahui bahwa jumlah tahu yang dihasilkan oleh Responden 5 (Bapak Gepeng) dalam satu kali proses produksi adalah : tahu goreng sebanyak 1.500 potong dengan ukuran $4 \times 4 \times 2 \mathrm{~cm}$ dengan harga jual Rp 200/potong sehingga diperoleh penerimaan sebesar Rp 300.000. Tahu Cina mentah sebanyak 1.500 potong dengan ukuran $4 \mathrm{x}$ $4 \times 2 \mathrm{~cm}$ dengan harga jual Rp 200/potong sehingga diperoleh penerimaan sebesar $\mathrm{Rp}$ 300.000. Tahu cina $1 / 2$ matang sebanyak 200 potong dengan ukuran $6 \times 6 \times 2 \mathrm{~cm}$ dan harga jual Rp 500/potong sehingga diperoleh penerimaan sebesar Rp 100.000. 
c. Aziz (Tabel 12)

\begin{tabular}{llrrr}
\hline \multirow{2}{*}{ No } & \multicolumn{1}{c}{ Uraian } & \multicolumn{3}{c}{ Produk Tahu } \\
\cline { 2 - 5 } & Tahu Goreng & Tahu Cina & Tahu 1/2 Matang \\
\hline 1. & Jumlah Tahu (Ptng/PP) & 1.000 & 600 & 40 \\
2. & Ukuran Tahu $\left(\mathrm{Cm}^{3}\right)$ & $4 \times 4 \times 2$ & $4 \times 4 \times 2$ & $6 \times 6 \times$ \\
3. & Kemasan & Plastik & Plastik & Plasti \\
4. & Harga (Rp/Potong) & 200 & 200 & 50 \\
5. & Penerimaan (Rp/proses) & 200.000 & 120.000 & 200.00
\end{tabular}

Sumber: Data Primer, 2014.

Berdasarkan tabel di atas dapat diketahui bahwa jumlah tahu yang dihasilkan oleh Responden 6 (Bapak Aziz) dalam satu kali proses produksi adalah: tahu goreng sebanyak 1.000 potong dengan ukuran 4 × 4 x $2 \mathrm{~cm}$ dengan harga jual Rp 200/potong sehingga diperoleh penerimaan sebesar Rp 200.000. Tahu Cina mentah sebanyak 600 potong dengan ukuran $6 \times 6$ x $2 \mathrm{~cm}$ dengan harga jual Rp 200/potong sehingga diperoleh penerimaan sebesar Rp 120.000. Tahu cina $1 / 2$ matang sebanyak 400 potong dengan ukuran 6 × 6 × $2 \mathrm{~cm}$ dan harga jual Rp 500/potong sehingga diperoleh penerimaan sebesar $\mathrm{Rp}$ 200.000 .

3. Industri Tahu dengan Kebutuhan Kedelai < $500 \mathrm{Kg} /$ Bulan.

a. Mukti (Tabel 13)

\begin{tabular}{llrrr}
\hline \multirow{2}{*}{ No } & \multicolumn{3}{c}{ Uraian } & \multicolumn{3}{c}{ Produk Tahu } \\
\cline { 3 - 5 } & & Tahu Goreng & Tahu Cina & Tahu 1/2 Matang \\
\hline 1. & Jumlah Tahu (Ptng/PP) & 550 & 200 & 200 \\
2. & Ukuran Tahu $\left(\mathrm{Cm}^{3}\right)$ & $4 \times 4 \times 2$ & $6 \times 5 \times 2,5$ & $6 \times 5 \times 2,5$ \\
3. & Kemasan & Plastik & Plastik & Plastik \\
4. & Harga (Rp/Potong) & 200 & 500 & 500 \\
5. & Penerimaan (Rp/proses) & 110.000 & 100.000 & 100.000 \\
\hline
\end{tabular}

Sumber: Data Primer, 2014.

Berdasarkan tabel di atas dapat diketahui bahwa jumlah tahu yang dihasilkan oleh Responden 7 (Bapak Mukti) dalam satu kali proses produksi adalah : tahu goreng sebanyak 550 potong dengan ukuran $4 \times 4 \times 2 \mathrm{~cm}$ dengan harga jual Rp 200/potong sehingga diperoleh penerimaan sebesar $\mathrm{Rp}$ 110.000. Tahu Cina mentah sebanyak 200 potong dengan ukuran 6 × 5 x 2,5 cm dengan harga jual Rp 500/potong sehingga diperoleh penerimaan sebesar $\mathrm{Rp}$ 100.000. Tahu cina $1 / 2$ matang sebanyak 900 potong dengan ukuran $6 \times 5 \times 2,5 \mathrm{~cm}$ dan harga jual $\mathrm{Rp}$ 500/potong sehingga diperoleh penerimaan sebesar Rp 100.000.

b. Markum (Tabel 14)

\begin{tabular}{llrrr}
\hline \multirow{2}{*}{ No } & \multicolumn{1}{c}{ Uraian } & \multicolumn{3}{c}{ Produk Tahu } \\
\cline { 2 - 5 } & & Tahu Goreng & Tahu Cina & Tahu 1/2 Matang \\
\hline 1. & Jumlah Tahu (Ptng/PP) & 700 & 700 & 600 \\
2. & Ukuran Tahu $\left(\mathrm{Cm}^{3}\right)$ & $4 \times 4 \times 2$ & $4 \times 4 \times 2$ & $4 \times 4 \times 2$ \\
3. & Kemasan & Plastik & Plastik & Plastik \\
4. & Harga (Rp/Potong) & 200 & 200 & 200 \\
5. & Penerimaan (Rp/proses) & 140.000 & 140.000 & 120.000 \\
\hline
\end{tabular}

Sumber: Data Primer, 2014.
Berdasarkan tabel dapat diketahui bahwa jumlah tahu yang dihasilkan oleh Responden 8 (Bapak Markum) dalam satu kali proses produksi adalah : tahu goreng sebanyak 700 potong dengan ukuran 4 x 4 x $2 \mathrm{~cm}$ dengan harga jual $\mathrm{Rp}$ 200/potong sehingga diperoleh penerimaan sebesar Rp 120.000. Tahu Cina mentah sebanyak 700 potong dengan ukuran $4 \times 4 \times 2 \mathrm{~cm}$ dengan harga jual Rp 200/potong sehingga diperoleh penerimaan sebesar Rp 1400.000. Tahu cina 1/2 matang sebanyak 600 potong dengan ukuran 4 x 4 x $2 \mathrm{~cm}$ dan harga jual Rp 200/potong sehingga diperoleh penerimaan sebesar Rp 120.000.

c. Wakiran (Tabel 15)

\begin{tabular}{llrrr}
\hline \multirow{2}{*}{ No } & \multicolumn{1}{c}{ Uraian } & \multicolumn{3}{c}{ Produk Tahu } \\
\cline { 3 - 5 } & & Tahu Goreng & Tahu Cina & Tahu $1 / 2$ Matang \\
\hline 1. & Jumlah Tahu (Ptng/PP) & 600 & 300 & 250 \\
2. & Ukuran Tahu (Cm $\left.{ }^{3}\right)$ & $4 \times 4 \times 2$ & $6 \times 6 \times 2$ & $6 \times 6 \times 2$ \\
3. & Kemasan & Plastik & Plastik & Plastik \\
4. Harga (Rp/Potong) & 200 & 450 & 500 \\
5. Penerimaan (Rp/proses) & 120.000 & 135.000 & 125.000
\end{tabular}

Sumber: Data Primer, 2014.

Berdasarkan tabel di atas dapat diketahui bahwa jumlah tahu yang dihasilkan oleh Responden 9 (Bapak Wakiran) dalam satu kali proses produksi adalah : tahu goreng sebanyak 600 potong dengan ukuran $4 \times 4 \times 2 \mathrm{~cm}$ dengan harga jual Rp 200/potong sehingga diperoleh penerimaan sebesar $\mathrm{Rp}$ 120.000. Tahu Cina mentah sebanyak 300 potong dengan ukuran $6 \times 6$ x $2 \mathrm{~cm}$ dengan harga jual Rp 450/potong sehingga diperoleh penerimaan sebesar Rp 135.000. Tahu cina $1 / 2$ matang sebanyak 250 potong dengan ukuran 6 × 6 × $2 \mathrm{~cm}$ dan harga jual Rp 500/potong sehingga diperoleh penerimaan sebesar $\mathrm{Rp}$ 125.000 .

Berdasarkan penelitian dan penjelasan di atas dapat disimpulkan bahwa diversifikasi (keanekaragaman) produk tahu yang dihasilkan industri tahu di Kabupaten OKU Timur baik yang dihasilkan oleh industri tahu dengan kapasitas kebutuhan kedelai $>1.000 \mathrm{Kg}, 500-1.000 \mathrm{Kg}$ maupun $<500 \mathrm{Kg}$ perbulan terdapat 3 macam tahu yang dihasilkan yaitu : tahu goreng, tahu cina mentah (tahu putih) dan tahu cina setengah matang. Produksi tahu yang dihasilkan juga berbeda-beda tergantung dengan kedelai yang digunakan. Semakin banyak kedelai yang diproses maka semakin banyak tahu yang dihasilkan. Harga jual tahu juga bervariasi yaitu tahu goreng rata-rata dijual dengan harga Rp 200/potong. Tahu cina mentah dijual debngan harga rata-rata $\mathrm{Rp}$ 450/ptong. Tahu Cina setengah matang di jual dengan harga antara Rp 200-500/potong. Adapun 
Ukuran tahu goreng rata-rata adalah $4 \times 4 \times 2 \mathrm{~cm}$. Tahu Cina mentah rata-rata ukurannya sama dengan tahu Cina setengah matang yaitu $6 \times 6 \times 2$ $\mathrm{cm}$.

\section{Analisa Biaya Usaha Industri Tahu di Kabupaten OKU Timur.}

Analisa usaha digunakan sebagai tolak ukur suatu usaha apakah menguntungkan atau tidak dan apakah usaha tersebut layak untuk dikembangkan atau tidak. Untuk menganalisa usaha adalah dengan menghitung berapa besar biaya produksi yang dikeluarkan, berapa jumlah produksi tahu, berapa besar penerimaan dan pendapatan yang diperoleh oleh responden. Dalam penelitian ini, biaya adalah biaya total dikeluarkan dalam usaha pembuatan tahu. Biaya total meliputi biaya tetap dan biaya variabel yang keduannya dinyatakan dalam rupiah.

\section{Biaya Tetap}

Biaya tetap adalah biaya yang besarnya tidak dipengaruhi oleh jumlah produksi. Biaya tetap dalam usaha pembuatan tahu meliputi biaya penyusutan peralatan dan biaya sewa tempat produksi. Besarnya biaya tetap yang dikeluarkan oleh setiap pengusaha berdasarkan kebutuhan kedelai yang digunakan dapat dilihat pada tabel berikut ini :

Tabel 16. Biaya Tetap Industri Tahu di Kabupaten

OKU Timur Kebutuhan Kedelai > 1.000 $\mathrm{Kg} /$ Bulan.

\begin{tabular}{|c|c|c|c|c|c|c|c|}
\hline $\mathrm{N}_{0}$ & Nama & $\begin{array}{c}\text { Nilai } \\
\text { Sewa } \\
\text { (Rp/Lg/PP) } \\
\end{array}$ & $\begin{array}{c}\text { Nilai } \\
\text { Sewa } \\
\text { (Rp/Lg/Bln) }\end{array}$ & $\begin{array}{c}\text { Penyusutan } \\
\text { Alat } \\
\text { (Rp/PP) } \\
\end{array}$ & $\begin{array}{c}\text { Penyusutan } \\
\text { Alat } \\
\text { (Rp/Bln) } \\
\end{array}$ & $\begin{array}{l}\text { Biaya } \\
\text { Tetap } \\
(\mathrm{Rp} / \mathrm{PP}) \\
\end{array}$ & $\begin{array}{c}\text { Biaya Tetap } \\
\text { (Rp/Bln) }\end{array}$ \\
\hline 1 & Jumingan & 8.333 & 250.000 & 9.702 & 291.056 & 18.035 & 541.056 \\
\hline 2 & Sujarno & 8.333 & 250.000 & 6.126 & 183.779 & 14.459 & 433.779 \\
\hline 3 & Solikin & 8.333 & 250.000 & 5.740 & 172.201 & 14.073 & 422.201 \\
\hline Jumlah & & 25.000 & 750.000 & 21.568 & 647.036 & 46.568 & 1.397 .036 \\
\hline Rerata & & 8.333 & 250.000 & 7.189 & 215.679 & 15.523 & 465.679 \\
\hline
\end{tabular}

Sumber: Olahan Data Primer, 2014.

Berdasarkan tabel diatas menunjukkan bahwa rata-rata biaya sewa lahan industri tahu dengan kebutuhan kedelai $>1.000 \mathrm{Kg} / \mathrm{bulan}$ untuk satu kali proses adalah sebesar $\mathrm{Rp} 8.333$ atau $\mathrm{Rp}$ 250.000/Bulan. Biaya penyusutan alat dalam satu kali proses produksi yaitu sebesar Rp 7.189 atau sebesar Rp 215.679/Bulan. Besarnya biaya tetap yang terdiri dari biaya sewa tempat dan penyusutan alat dalam satu kali proses produksi adalah sebesar $\mathrm{Rp} 15.523$ atau sebesar $\mathrm{Rp}$ 465.679/Bulan.

Tabel 17. Biaya Tetap Industri Tahu di Kabupaten OKU Timur Kebutuhan Kedelai 500 $1.000 \mathrm{Kg} / \mathrm{Bulan}$.

\begin{tabular}{|c|c|c|c|c|c|c|c|}
\hline No & Nama & $\begin{array}{c}\text { Nilai } \\
\text { Sewa } \\
\text { (Rp/Lg/PP) }\end{array}$ & $\begin{array}{c}\text { Nilai } \\
\text { Sewa } \\
(\mathrm{Rp} / \mathrm{Lg} / \mathrm{Bln})\end{array}$ & $\begin{array}{l}\text { Penyusutan } \\
\text { Alat } \\
\text { (Rp/PP) }\end{array}$ & $\begin{array}{c}\text { Penyusutan } \\
\quad \text { Alat } \\
(\mathrm{Rp} / \mathrm{Bln})\end{array}$ & $\begin{array}{l}\text { Biaya } \\
\text { Tetap } \\
(\mathrm{Rp} / \mathrm{PP})\end{array}$ & $\begin{array}{l}\text { Biaya Tetap } \\
(\mathrm{Rp} / \mathrm{Bn})\end{array}$ \\
\hline 1 & Muhammad & 7.778 & 233.333 & 5.174 & 155.211 & 12.951 & 388.544 \\
\hline 2 & Gepeng & 8.333 & 250.000 & 4.068 & 122.044 & 12.401 & 372.044 \\
\hline 3 & Aziz & 8.333 & 250.000 & 3.871 & 116.131 & 12.204 & 366.131 \\
\hline Juml & & 24.444 & 733.333 & 13.113 & 393.386 & 37.557 & 1.126 .719 \\
\hline Rera & & 8.148 & 244.444 & 4.371 & 131.129 & 12.519 & 375.573 \\
\hline
\end{tabular}

Sumber: Olahan Data Primer, 2014.

Berdasarkan tabel diatas menunjukkan bahwa rata-rata biaya sewa lahan industri tahu dengan kebutuhan kedelai $500-1.000 \mathrm{Kg} /$ bulan untuk satu kali proses produksi adalah sebesar $\mathrm{Rp}$ 8.148 atau sebesar Rp 244.444/Bulan. Biaya penyusutan alat dalam satu kali proses produksi yaitu sebesar $\mathrm{Rp} 4.371$ atau sebesar $\mathrm{Rp}$ 131.129/Bulan. Besarnya biaya tetap yang terdiri dari biaya sewa tempat dan biaya penyusutan alat dalam satu kali proses produksi adalah sebesar Rp 12.519 atau sebesar Rp 375.573/Bulan.

Tabel 18. Biaya Tetap Industri Tahu di Kabupaten OKU Timur Kebutuhan Kedelai $<500$ $\mathrm{Kg} /$ Bulan.

\begin{tabular}{|c|c|c|c|c|c|c|c|}
\hline No & $\mathrm{Nawa}$ & $\begin{array}{c}\text { Nalai } \\
\text { Sewa } \\
(\mathrm{Rp} / \mathrm{Lg} \mathrm{FP})\end{array}$ & $\begin{array}{c}\text { Nlai } \\
\text { Sema } \\
(\mathrm{Rp̣} / \mathrm{Lg} \mathrm{Bh})\end{array}$ & $\begin{array}{c}\text { Penyusutam } \\
\text { Alat } \\
\text { (Rp̣pP) }\end{array}$ & $\begin{array}{c}\text { Penyusutan } \\
\text { Alat } \\
(\mathrm{Rp} / \mathrm{Bln})\end{array}$ & $\begin{array}{l}\text { Baya } \\
\text { Tetap } \\
\text { (RọpP) }\end{array}$ & $\begin{array}{l}\text { Bayz Tetay } \\
(\mathrm{Rpo} / \mathrm{Bln})\end{array}$ \\
\hline 1 & Multi & 7.22 & 216.667 & 2850 & 85.508 & 10.073 & 302.175 \\
\hline 2 & Markum & 5.833 & 175.000 & 3.132 & 93.950 & 8.965 & 268.950 \\
\hline 3 & Waliran & 8.056 & 241.667 & 2.947 & 88.399 & 11.002 & 330.065 \\
\hline Jumlah & & 21.111 & 633333 & 8.929 & 267.857 & 30.040 & 901.19] \\
\hline Rerata & & 7.037 & 211.111 & 2.976 & 89.286 & 10.013 & 300.397 \\
\hline
\end{tabular}

Sumber: Olahan Data Primer, 2014.

Berdasarkan tabel diatas menunjukkan bahwa rata-rata biaya sewa lahan industri tahu dengan kebutuhan kedelai $<500 \mathrm{Kg} / \mathrm{bulan}$ untuk satu kali proses adalah sebesar Rp 7.037 atau sebesar Rp 211.111/Bulan. Biaya penyusutan alat industri tahu dengan kebutuhan kedelai $<500$ $\mathrm{Kg} /$ bulan dalam satu kali proses produksi yaitu sebesar Rp 2.976 atau sebesar Rp 89.286/Bulan. Besarnya biaya tetap yang terdiri dari biaya sewa tempat dan biaya penyusutan alat industri tahu dengan kebutuhan kedelai $<500 \mathrm{Kg} /$ bulan dalam satu kali proses produksi adalah sebesar $\mathrm{Rp}$ 10.013 atau sebesar Rp 300.397/Bulan.

\section{Biaya Variabel}

Biaya variabel adalah biaya yang besar kecilnya sangat tergantung kepada skala produksi dan akan habis dalam satu kali proses produksi. Biaya variabel dalam usaha pembuatan tahu meliputi; biaya bahan baku produksi (saprodi) dan biaya tenaga kerja yang dinyatakan dalam satuan rupiah. Besarnya biaya variabel dapat dilihat pada tabel berikut ini : 
Tabel 19. Biaya Variabel Industri Tahu di Kabupaten OKU Timur Kebutuhan Kedelai > $1.000 \mathrm{Kg} /$ Bulan.

\begin{tabular}{cccccccc}
\hline No & Nama & $\begin{array}{c}\text { Biaya } \\
\text { Saprodi } \\
(\mathrm{Rp} / \mathrm{PP})\end{array}$ & $\begin{array}{c}\text { Biaya } \\
\text { Saprodi } \\
(\mathrm{Rp} / \mathrm{Bhn})\end{array}$ & $\begin{array}{c}\text { Tenaga } \\
\text { Kerja } \\
(\mathrm{Rp} / \mathrm{PP})\end{array}$ & $\begin{array}{c}\text { Tenaga } \\
\text { Kerja } \\
(\mathrm{Rp} / \mathrm{Bln})\end{array}$ & $\begin{array}{c}\text { Biaya } \\
\text { Variabel } \\
(\mathrm{Rp} / \mathrm{PP})\end{array}$ & $\begin{array}{c}\text { Biaya Variabel } \\
(\mathrm{Rp} / \mathrm{Bh})\end{array}$ \\
\hline 1 & Juningan & 1.560 .500 & 46.815 .000 & 200.000 & 6.000 .000 & 1.760 .500 & 52.815 .000 \\
2 & Sujamo & 981.000 & 29.430 .000 & 150.000 & 4.500 .000 & 1.131 .000 & 33.930 .000 \\
3 & Solihin & 652.000 & 19.560 .000 & 120.000 & 3.600 .000 & 772.000 & 23.160 .000 \\
\hline Jumlah & 3.193 .500 & 95.805 .000 & 470.000 & 14.100 .000 & 3.663 .500 & 109.905 .000 \\
Rerata & 1.064 .500 & 31.935 .000 & 156.667 & 4.700 .000 & 1.221 .167 & 36.635 .000 \\
\hline
\end{tabular}

Sumber: Olahan Data Primer, 2014.

Tabel diatas menunjukkan bahwa biaya variabel yang terdiri dari biaya sarana produksi dan biaya tenaga kerja. Biaya sarana produksi meliputi pembelian kedelai, minyak goreng, kayu bakar, ragi, air bersih, BBM dan plastik. Adapun besarnya biaya sarana produksi industri tahu dengan kebutuhan kedelai $>1.000 \mathrm{Kg}$ per bulan dalam satu kali proses produksi adalah sebesar $\mathrm{Rp}$ 1.064.500 atau sebesar Rp 31.935.000/Bulan. Besarnya biaya tenaga kerja dalam satu kali proses produksi adalah Rp 156.667 atau sebesar $\mathrm{Rp}$ 4.700.000. Rata-rata biaya variabel industri tahu dengan kebutuhan kedelai $>1.000 \mathrm{Kg}$ yang terdiri dari biaya saprodi dan biaya tenaga kerja dalam satu kali proses produksi adalah sebesar Rp 1.221.167 atau sebesar Rp 36.635.000/Bulan.

Tabel 20. Biaya Variabel Industri Tahu di Kabupaten OKU Timur Kebutuhan Kedelai 500- $1.000 \mathrm{Kg} /$ Bulan.

\begin{tabular}{|c|c|c|c|c|c|c|c|}
\hline No & Nama & $\begin{array}{l}\text { Biaya } \\
\text { Saprodi } \\
(\mathrm{Rp} / \mathrm{PP})\end{array}$ & $\begin{array}{c}\text { Biaya } \\
\text { Saprodi } \\
(\mathrm{Rp} / \mathrm{Bln})\end{array}$ & $\begin{array}{l}\text { Tenaga } \\
\text { Kerja } \\
(\mathrm{Rp} / \mathrm{PP})\end{array}$ & $\begin{array}{l}\text { Tenaga } \\
\text { Kerja } \\
(\mathrm{Rp} / \mathrm{Bn})\end{array}$ & $\begin{array}{l}\text { Biaya } \\
\text { Variabel } \\
(\mathrm{Rp} / \mathrm{PP})\end{array}$ & $\begin{array}{l}\text { Biaya Variabel } \\
(\mathrm{R} p / \mathrm{Bn})\end{array}$ \\
\hline 1 & Muhammad & 455.000 & 13.650 .000 & 100.000 & 3.000 .000 & 555.000 & 16.650 .000 \\
\hline 2 & Gepeng & 507.000 & 15.210 .000 & 100.000 & 3.000 .000 & 607.000 & 18.210 .000 \\
\hline 3 & Azzz & 344,000 & 10.320 .000 & 80.000 & 2.400 .000 & 424.000 & 12.720 .000 \\
\hline Jumlah & & 1.306 .000 & 39.180 .000 & 280.000 & 8.400 .000 & 1.586 .000 & 47.580 .000 \\
\hline Rerata & & 435.333 & 13.060 .000 & 93.333 & 28000.000 & 528.667 & 15.860 .000 \\
\hline
\end{tabular}

Sumber: Olahan Data Primer, 2014.

Tabel diatas menunjukkan bahwa biaya variabel yang terdiri dari biaya sarana produksi dan biaya tenaga kerja. Besarnya rata-rata biaya saprodi dalam satu kali proses produksi adalah sebesar Rp 435.333 atau sebesar $\mathrm{Rp}$ 13.060.000/Bulan. Besarnya biaya tenaga kerja dalam satu kali proses produksi adalah Rp 93.333 atau sebesar Rp 2.800.000. Rata-rata biaya variabel industri tahu dengan kebutuhan kedelai 500-1.000 Kg yang terdiri dari biaya saprodi dan biaya tenaga kerja dalam satu kali proses produksi adalah sebesar Rp 528.667 atau sebesar Rp 15.860.000/Bulan.

Tabel 21. Biaya Variabel Industri Tahu di Kabupaten OKU Timur Kebutuhan Kedelai $<500 \mathrm{Kg} /$ Bulan.

\begin{tabular}{|c|c|c|c|c|c|c|c|}
\hline No & Nama & $\begin{array}{l}\text { Biaya } \\
\text { Saprodi } \\
(\mathrm{Rp} / \mathrm{PP})\end{array}$ & $\begin{array}{c}\text { Biaya } \\
\text { Saprodi } \\
(\mathrm{Rp} / \mathrm{Bln})\end{array}$ & $\begin{array}{l}\text { Tenaga } \\
\text { Kerja } \\
(\mathrm{Rp} / \mathrm{PP})\end{array}$ & $\begin{array}{c}\text { Tenaga } \\
\text { Kerja } \\
(\mathrm{Rp} / \mathrm{Bl})\end{array}$ & $\begin{array}{c}\text { Biaya } \\
\text { Variabel } \\
(\mathrm{Rp} / \mathrm{PP}) \\
\end{array}$ & $\begin{array}{c}\text { Biaya Varabel } \\
(\mathrm{Rp} / \mathrm{Bn}) \\
\end{array}$ \\
\hline 1 & Multi & 198.100 & 5.943 .000 & 50.000 & 1.500 .000 & 248.100 & 7.443 .000 \\
\hline 2 & Markum & 262.400 & 7.872 .000 & 80.000 & 2.400 .000 & 342.400 & 10.272 .000 \\
\hline 3 & Wakiran & 245.500 & 7.365 .000 & 70.000 & 2.100 .000 & 315.500 & 9.465 .000 \\
\hline Jumlah & & 706.000 & 21.180 .000 & 200.000 & 6.000 .000 & 906.000 & 27.180 .000 \\
\hline Rerata & & 235.333 & 7.060 .000 & 66.667 & 2.000 .000 & 302.000 & 9.060 .000 \\
\hline
\end{tabular}

Sumber: Olahan Data Primer, 2014.

Tabel diatas menunjukkan bahwa besarnya rata-rata biaya saprodi dalam satu kali proses produksi adalah sebesar Rp 235.333 atau sebesar Rp 7.060.000/Bulan. Besarnya biaya tenaga kerja dalam satu kali proses produksi adalah Rp 66.667 atau sebesar Rp 2.000.000. Rata-rata biaya variabel industri tahu dengan kebutuhan kedelai < $500 \mathrm{Kg}$ per bulan yang terdiri dari biaya saprodi dan biaya tenaga kerja dalam satu kali proses produksi adalah sebesar Rp 302.000 atau sebesar Rp 9.060.000/Bulan.

\section{Biaya Total}

Biaya total adalah semua biaya yang digunakan dalam usaha pembuatan tahu yang meliputi total biaya tetap dan total biaya variabel. Besarnya biaya total usaha pembuatan tahu di Kabupaten OKU Timur dapat dilihat pada Tabel berikut:

Tabel 22. Biaya Total Produksi Industri Tahu di Kabupaten OKU Timur Kebutuhan Kedelai > $1.000 \mathrm{Kg} /$ Bulan.

\begin{tabular}{|c|c|c|c|c|c|c|c|}
\hline No & Nama & $\begin{array}{c}\mathrm{FC} \\
(\mathrm{Rp} / \mathrm{PP}) \\
\end{array}$ & $\begin{array}{c}\text { FC } \\
(\mathrm{Rp} / \mathrm{Bln}) \\
\end{array}$ & $\begin{array}{c}\mathrm{VC} \\
(\mathrm{Rp} / \mathrm{PP}) \\
\end{array}$ & $\begin{array}{c}\mathrm{VC} \\
\text { (Rp/Bln) } \\
\end{array}$ & $\begin{array}{c}\mathrm{TC} \\
(\mathrm{Rp} / \mathrm{PP}) \\
\end{array}$ & $\begin{array}{c}\mathrm{TC} \\
(\mathrm{Rp} / \mathrm{Bln}) \\
\end{array}$ \\
\hline 1 & Jumingan & 18.035 & 541.056 & 1.760 .500 & 52.815 .000 & 1.778 .535 & 53.356 .056 \\
\hline 2 & Sujarno & 14.459 & 433.779 & 1.131 .000 & 33.930 .000 & 1.145 .459 & 34.363 .779 \\
\hline 3 & Solikin & 14.073 & 422.201 & 772.000 & 23.160 .000 & 786.073 & 23.582 .201 \\
\hline Jumlah & & 46.568 & 1.397 .036 & 3.663 .500 & 109.905 .000 & 3.710 .068 & 111.302 .036 \\
\hline Rerata & & 15.523 & 465.679 & 1.221 .167 & 36.635 .000 & 1.236 .689 & 37.100 .679 \\
\hline
\end{tabular}

Sumber: Olahan Data Primer, 2014.

Tabel 22 menunjukkan bahwa biaya total yang terdiri dari biaya tetap dan biaya variabel industri tahu dengan kebutuhan kedelai > 1.000 $\mathrm{Kg} /$ Bulan dalam satu kali proses produksi adalah sebesar Rp 1.236.689 atau biaya total produksi dalam satu bulan adalah sebesar Rp 37.100.679.

Tabel 23. Biaya Total Produksi Industri Tahu di Kabupaten OKU Timur Kebutuhan Kedelai $500-1.000 \mathrm{Kg} /$ Bulan.

\begin{tabular}{|c|c|c|c|c|c|c|c|}
\hline № & Nama & $\begin{array}{c}\mathrm{FC} \\
(\mathrm{Rp} / \mathrm{PP}) \\
\end{array}$ & $\begin{array}{c}\mathrm{FC} \\
(\mathrm{Rp} / \mathrm{Bln}) \\
\end{array}$ & $\begin{array}{c}\mathrm{VC} \\
(\mathrm{Rp} / \mathrm{PP}) \\
\end{array}$ & $\begin{array}{c}\mathrm{VC} \\
\text { (Rp/Bln) }\end{array}$ & $\begin{array}{c}\mathrm{TC} \\
(\mathrm{Rp} / \mathrm{PP}) \\
\end{array}$ & $\begin{array}{c}\mathrm{TC} \\
\text { (Rp/Bln) }\end{array}$ \\
\hline 1 & Muhammad & 12.951 & 388.544 & 555.000 & 16.650 .000 & 567.951 & 17.038.544 \\
\hline 2 & Gepeng & 12.401 & 372.044 & 607.000 & 18.210 .000 & 619.401 & 18.582 .044 \\
\hline 3 & Aziz & 12.204 & 366.131 & 424.000 & 12.720 .000 & 436.204 & 13.086.131 \\
\hline Jumlah & & 37.557 & 1.126 .719 & 1.586 .000 & 47.580 .000 & 1.623 .557 & 48.706 .719 \\
\hline Rerata & & 12.519 & 375.573 & 528.667 & 15.860 .000 & 541.186 & 16.235 .573 \\
\hline
\end{tabular}

Sumber: Olahan Data Primer, 2014.

Tabel 23 menunjukkan bahwa biaya total yang terdiri dari biaya tetap dan biaya variabel 
industri tahu dengan kebutuhan kedelai 500$1.000 \mathrm{Kg} /$ Bulan dalam satu kali proses produksi adalah sebesar Rp 541.186 atau biaya total produksi dalam satu bulan adalah sebesar $\mathrm{Rp}$ 16.235.573.

Tabel 24. Biaya Total Produksi Industri Tahu di Kabupaten OKU Timur Kebutuhan Kedelai 500-1.000 Kg/Bulan.

\begin{tabular}{|c|c|c|c|c|c|c|c|}
\hline No & Nama & $\begin{array}{c}\mathrm{FC} \\
(\mathrm{Rp} / \mathrm{PP})\end{array}$ & $\begin{array}{c}\mathrm{FC} \\
(\mathrm{Rp} / \mathrm{Bln})\end{array}$ & $\begin{array}{c}\mathrm{VC} \\
(\mathrm{Rp} / \mathrm{PP})\end{array}$ & $\begin{array}{c}\mathrm{VC} \\
\text { (Rp/Bln) }\end{array}$ & $\begin{array}{c}\mathrm{TC} \\
(\mathrm{Rp} / \mathrm{PP})\end{array}$ & $\begin{array}{c}\mathrm{TC} \\
\text { (Rp/Bln) }\end{array}$ \\
\hline 1 & Mukti & 10.073 & 302.175 & 248.100 & 7.443 .000 & 258.173 & 7.745 .175 \\
\hline 2 & Markum & 8.965 & 268.950 & 342.400 & 10.272 .000 & 351.365 & 10.540 .950 \\
\hline 3 & Wakiran & 11.002 & 330.065 & 315.500 & 9.465 .000 & 326.502 & 9.795 .065 \\
\hline Jumlah & & 30.040 & 901.191 & 906.000 & 27.180 .000 & 936.040 & 28.081 .191 \\
\hline Rerata & & 10.013 & 300.397 & 302.000 & 9.060 .000 & 312.013 & 9.360 .397 \\
\hline
\end{tabular}

Sumber: Olahan Data Primer, 2014.

Tabel 24 menunjukkan bahwa biaya total yang terdiri dari biaya tetap dan biaya variabel industri tahu dengan kebutuhan kedelai $<500$ $\mathrm{Kg} / \mathrm{Bulan}$ dalam satu kali proses produksi adalah sebesar Rp 312.013 atau biaya total produksi dalam satu bulan adalah sebesar Rp 9.360.397.

\section{Analisa Penerimaan dan Pendapatan Usaha Pembuatan Tahu. \\ 1. Penerimaan}

Penerimaan merupakan perkalian antara total produk yang terjual dengan harga persatuan produk. Penerimaan usaha industri tahu berasal dari tahu yang terjual. Adapun rerata produksi, harga dan penerimaan pada industri pembuatan tahu di kabupaten OKU Timur disajikan pada tabel berikut ini.

Tabel 25. Produksi, Harga dan Penerimaan Industri Tahu di Kabupaten OKU Timur Kebutuhan Kedelai > 1.000 $\mathrm{Kg} /$ Bulan.

\begin{tabular}{|c|c|c|c|c|c|c|c|c|c|c|c|c|}
\hline \multirow[b]{2}{*}{$\mathrm{N}_{0}$} & \multirow[b]{2}{*}{ Nama } & \multicolumn{3}{|c|}{ Produksi Tahu (Potong) } & \multicolumn{3}{|c|}{ Harga Jual (RppPtng) } & \multicolumn{3}{|c|}{ Penerimaan (Rp/PP) } & \multicolumn{2}{|c|}{ Total Penerimaan } \\
\hline & & Goreng & $\begin{array}{l}\text { Cima } \\
\text { Mentah }\end{array}$ & $\begin{array}{l}1 / 2 \\
\text { matang }\end{array}$ & Goreng & $\begin{array}{l}\text { Cima } \\
\text { Mentah }\end{array}$ & $\begin{array}{l}1 / 2 \\
\text { matang }\end{array}$ & Goreng & $\begin{array}{l}\text { Cina } \\
\text { Mentah }\end{array}$ & $1 / 2$ matang & $(\mathrm{Rp} P \mathrm{PP})$ & $(R)$ \\
\hline 1 & Jumingan & 3.000 & 2.40 & 900 & 200 & 45 & 500 & 600.000 & 1.080 .000 & 450.000 & 2.130 .000 & 63.900 .000 \\
\hline 2 & Sujarno & 2000 & 1.000 & 1.000 & 200 & 45 & 500 & 400.000 & 450.000 & 500.000 & 1.350 .000 & 40.500 .000 \\
\hline & Solkin & 1.800 & 950 & 500 & 200 & 45 & 500 & 360.000 & 427.500 & 250.000 & 1.037 .500 & 31.125 .000 \\
\hline & Jumlah & 6.800 & 4.35 & 2.400 & 600 & 1.35 & 1.500 & 1.360 .000 & 1.957 .500 & 1.200 .000 & 4.517 .500 & 135.525 .000 \\
\hline & Rerata & 2.267 & 1.450 & 800 & 200 & 45 & 500 & 453.333 & 652.500 & 400.000 & 1.505 .833 & 45.175 .000 \\
\hline
\end{tabular}

Sumber: Olahan Data Primer, 2014.

Berdasarkan hasil perhitungan yang ditampilkan pada tabel 25 diatas, dapat diketahui bahwa rerata produksi tahu yang dihasilkan oleh responden industri tahu dengan kebutuhan kedelai $>1.000 \mathrm{Kg} / \mathrm{Bulan}$ dalam satu kali proses produksi adalah : tahu goreng sebanyak 2.267 potong, tahu cina mentah 1.450 potong, tahu cina $1 / 2$ matang sebanyak 800 potong. Rata-rata harga jual tahu goreng Rp 200/potong, harga tahu cina mentah Rp 450/potong dan tahu cina $1 / 2$ matang $\mathrm{Rp}$ 500/potong. Penerimaan yang diperoleh penjualan tahu goreng adalah sebesar $\mathrm{Rp}$ 453.333/PP, penerimaan tahu cina mentah $\mathrm{Rp}$ 652.500/PP dan penerimaan tahu cina $1 / 2$ matang adalah $\mathrm{Rp} 400.000 / \mathrm{PP}$. Adapun penerimaan total industri tahu adalah sebesar Rp 1.505.833/PP atau sebesar Rp 45.175.000/Bulan.

Tabel 26. Produksi, Harga dan Penerimaan Industri Tahu di Kabupaten OKU Timur Kebutuhan Kedelai 500 $1.000 \mathrm{Kg} / \mathrm{Bulan}$.

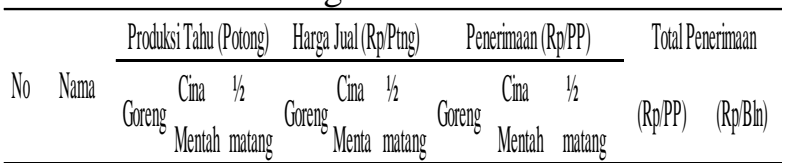

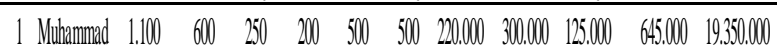

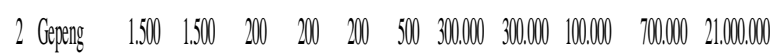

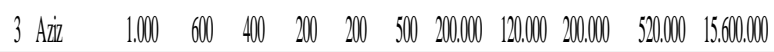

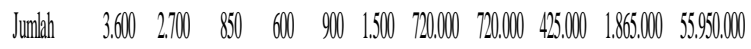

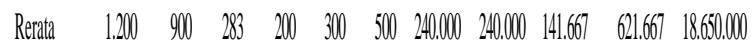
Sumber: Olahan Data Primer, 2014.

Berdasarkan hasil perhitungan yang ditampilkan pada tabel 26 diatas, dapat diketahui bahwa rerata produksi tahu yang dihasilkan oleh responden industri tahu dengan kebutuhan kedelai $500-1.000 \mathrm{Kg} / \mathrm{Bulan}$ dalam satu kali proses produksi adalah : tahu goreng sebanyak 1.200 potong, tahu cina mentah 900 potong, tahu cina $1 / 2$ matang sebanyak 283 potong. Rata-rata harga jual tahu goreng Rp 200/potong, harga tahu cina mentah $\mathrm{Rp} \mathrm{300/potong} \mathrm{dan} \mathrm{tahu} \mathrm{cina} 1 / 2$ matang $\mathrm{Rp}$ 500/potong. Penerimaan yang diperoleh penjualan tahu goreng dalam satu kali proses produksi adalah sebesar Rp 240.000, penerimaan tahu cina mentah sebesara Rp 240.000/Proses dan penerimaan tahu cina $1 / 2$ matang adalah $\mathrm{Rp}$ 141.667/Proses. Adapun penerimaan total industri tahu di Kabupaten OKU Timur dengan kebutuhan kedelai $500-1.000 \mathrm{Kg} / \mathrm{Bulan}$ dalam satu kali proses produksi adalah sebesar Rp 621.667 atau dalam satu bulan akan diperoleh penerimaan sebesar Rp 18.650.000.

Tabel 27. Produksi, Harga dan Penerimaan Industri Tahu di Kabupaten OKU Timur Kebutuhan Kedelai $<500$ $\mathrm{Kg} /$ Bulan.

\begin{tabular}{|c|c|c|c|c|c|c|c|c|c|c|c|c|}
\hline \multirow[b]{2}{*}{ No } & \multirow[b]{2}{*}{ Nama } & \multicolumn{3}{|c|}{ Produksi Tahu (Potong) } & \multicolumn{3}{|c|}{ Harga Jual (RpplPtng) } & \multicolumn{3}{|c|}{ Penerimaan (Rp/PP) } & \multicolumn{2}{|c|}{ Total Penerimaan } \\
\hline & & Goren & $\begin{array}{l}\text { Cina } \\
\text { Mentah }\end{array}$ & & & $\begin{array}{l}\text { Cina } \\
\text { Mentah }\end{array}$ & & Goreng & $\begin{array}{l}\text { Cima } \\
\text { Mentah }\end{array}$ & $\begin{array}{l}1 / 2 \\
\text { matang }\end{array}$ & $2(P P)$ & $(\mathrm{Rp} / \mathrm{Bln})$ \\
\hline 1 & Mukti & 550 & 200 & 200 & 200 & 500 & 500 & 110.000 & 100.000 & 100.000 & 310.000 & 9.300 .000 \\
\hline 2 & Markum & 700 & 700 & 600 & 200 & 200 & 200 & 140.000 & 140.000 & 120.000 & 400.000 & 12.000 .000 \\
\hline 3 & Wakiran & 600 & 300 & 250 & 200 & 450 & 500 & 120.000 & 135.000 & 125.000 & 380.000 & 11.400 .000 \\
\hline & Jumlah & 1.850 & 1.200 & 1.050 & 600 & 1.150 & 1.200 & 370.000 & 375.000 & 345.000 & 1.090 .000 & 32.700 .000 \\
\hline & Rerata & 617 & 400 & 350 & 200 & 383 & 400 & 123.333 & 125.000 & 115.000 & 363.333 & 10.900 .000 \\
\hline
\end{tabular}

Sumber: Olahan Data Primer, 2014.

Berdasarkan hasil perhitungan yang ditampilkan pada tabel 27 diatas, dapat diketahui 
bahwa rerata produksi tahu yang dihasilkan oleh responden industri tahu dengan kebutuhan kedelai $<500 \mathrm{Kg} / \mathrm{Bulan}$ dalam satu kali proses produksi adalah : tahu goreng sebanyak 617 potong, tahu cina mentah 400 potong, tahu cina $1 / 2$ matang sebanyak 350 potong. Rata-rata harga jual tahu goreng Rp 200/potong, harga tahu cina mentah Rp 383/potong dan tahu cina $1 / 2$ matang $\mathrm{Rp}$ 400/potong. Penerimaan yang diperoleh penjualan tahu goreng dalam satu kali proses produksi adalah sebesar Rp 123.333, penerimaan tahu cina mentah sebesara Rp 125.000/Proses dan penerimaan tahu cina $1 / 2$ matang adalah $\mathrm{Rp}$ 115.000/Proses. Adapun penerimaan total industri tahu di Kabupaten OKU Timur dengan kebutuhan kedelai < $500 \mathrm{Kg} /$ Bulan dalam satu kali proses produksi adalah sebesar $\mathrm{Rp} 363.333$ atau dalam satu bulan akan diperoleh penerimaan sebesar Rp 10.900.000.

\section{Pendapatan}

Pendapatan merupakan hasil berupa penerimaan yang diterima oleh responden setelah dikurangi total biaya produksi yang dikeluarkan dalam usaha pembuatan tahu. Nilai pendapatan ini merupakan hasil bersih yang diperoleh selama proses produksi. Hasil analisis pendapatan usaha industri tahu di Kabupaten OKU Timur secara keseluruhan dapat dilihat pada tabel berikut :

Tabel 28. Pendapatan Industri Tahu di Kabupaten OKU Timur Kebutuhan Kedelai > 1.000 $\mathrm{Kg} /$ Bulan.

\begin{tabular}{|c|c|c|c|c|c|c|c|}
\hline \multirow{2}{*}{ No Nama } & \multicolumn{2}{|c|}{ Penerimaan } & \multicolumn{2}{|c|}{ Biaya Total } & \multicolumn{2}{|c|}{ Pendapatan } & \\
\hline & $(\mathrm{Rp} / \mathrm{PP})$ & $(\mathrm{R} p \mathrm{~B} B \mathrm{n})$ & $(\mathrm{Rp} / \mathrm{P})$ & $(\mathrm{R} p \mathrm{~B} B \mathrm{n})$ & (Rp/PP) & $(\mathrm{Rp} / \mathrm{Bln})$ & \\
\hline 1 Jumingan & 2.130 .000 & 63,9000000 & 1.778 .535 & 533.356 .056 & 351.465 & 10.543 .94 & 1,20 \\
\hline 2 Sujarno & 1.350 .000 & 40.500 .000 & 1.145 .459 & 34.363 .779 & 204.541 & 6.136 .221 & 1,18 \\
\hline 3 Solikin & 1.037 .500 & 31.125 .000 & 786.073 & 23.582 .201 & 251.427 & 7.542 .799 & 1,32 \\
\hline Jumlah & 4.517 .500 & 135.525 .000 & 3.710 .068 & 111.302 .036 & 807.432 & 24.222 .964 & 3,70 \\
\hline Rerata & 1.505 .833 & 45.175 .000 & 1.236 .689 & 37.100 .679 & 269.144 & 8.074 .321 & 1,23 \\
\hline
\end{tabular}

Sumber: Olahan Data Primer, 2014.

Berdasarkan hasil perhitungan yang ditampilkan pada tabel 28 diatas, dapat diketahui bahwa total penerimaan yang diperoleh industri tahu dengan kebutuhan kedelai $>1.000 \mathrm{Kg} / \mathrm{Bulan}$ adalah sebesar Rp 1.505.833/Proses atau sebesar Rp 45.175.000/Bulan. Total biaya produksi adalah sebesar Rp 1.236.689/Proses atau sebesar Rp 37.100.679/Bulan sehingga pendapatan yang diperoleh dalam satu kali proses produksi industri tahu dengan kebutuhan kedelai $>1.000 \mathrm{Kg} /$ Bulan dalam satu kali proses produksi adalah sebesar Rp 269.144 atau sebesar Rp 8.074.321/Bulan. Nilai $\mathrm{R} / \mathrm{C}$ rasio industri tahu dengan kebutuhan kedelai $>1.000 \mathrm{Kg} /$ Bulan adalah sebesar 1,23 yang berarti setiap Rp 1 biaya yang dikeluarkan akan menghasilkan penerimaan sebesar Rp 1,23.

Tabel 29. Pendapatan Industri Tahu di Kabupaten OKU Timur Kebutuhan Kedelai 500$1.000 \mathrm{Kg} /$ Bulan.

\begin{tabular}{|c|c|c|c|c|c|c|c|c|}
\hline \multirow{2}{*}{ No } & \multirow{2}{*}{ Nama } & \multicolumn{2}{|c|}{ Penermaan } & \multicolumn{2}{|c|}{ Biaya Total } & \multicolumn{2}{|c|}{ Pendapatan } & \multirow{2}{*}{$\mathrm{R} / \mathrm{C}$} \\
\hline & & $(\mathrm{Rp} P \mathrm{PP})$ & $(\mathrm{Rp} \mathrm{Bh})$ & $(\mathrm{Rp} P \mathrm{PP})$ & $(\mathrm{Rp} / \mathrm{Bm})$ & $(\mathrm{Rp} P \mathrm{PP})$ & $(\mathrm{Rp} \mathrm{Bh})$ & \\
\hline 1 & Muhammad & 645.000 & 19.350 .000 & 567.951 & & 77.049 & & 1,14 \\
\hline 2 & Gepeng & 700.000 & 21.000 .000 & 619.401 & & 80.599 & & 1,13 \\
\hline 3 & Azzi & 520.000 & 15.600 .000 & 436.204 & & 83.796 & 2.513 .869 & 1,19 \\
\hline & Jumlah & 1.865 .000 & 55.950 .000 & 1.623 .557 & 48.706 .719 & 241.443 & 7.243 .281 & 3,46 \\
\hline & Rerata & 621.667 & 18.650 .000 & 541.186 & 16.235 .573 & 80.481 & 2.414 .427 & 1,15 \\
\hline
\end{tabular}

Sumber: Olahan Data Primer, 2014.

Berdasarkan hasil perhitungan yang ditampilkan pada tabel 29 diatas, dapat diketahui bahwa total penerimaan yang diperoleh industri tahu dengan kebutuhan kedelai 500-1.000 $\mathrm{Kg} /$ Bulan adalah sebesar Rp 621.667/Proses atau sebesar Rp 18.650.000/Bulan. Total biaya produksi adalah sebesar Rp 541.186/Proses atau sebesar Rp 16.235.573/Bulan sehingga pendapatan yang diperoleh dalam satu kali proses produksi industri tahu dengan kebutuhan kedelai 500-1.000 Kg/Bulan dalam satu kali proses produksi adalah sebesar $\mathrm{Rp} 80.481$ atau sebesar Rp 2.414.427/Bulan. Nilai R/C rasio industri tahu dengan kebutuhan kedelai 500-1.000 Kg/Bulan adalah sebesar 1,15 yang berarti setiap $\mathrm{Rp} 1$ biaya yang dikeluarkan akan menghasilkan penerimaan sebesar Rp 1,15.

Tabel 30. Pendapatan Industri Tahu di Kabupaten OKU Timur Kebutuhan Kedelai $<500$ $\mathrm{Kg} /$ Bulan.

\begin{tabular}{|c|c|c|c|c|c|c|c|c|}
\hline \multirow{2}{*}{$\mathrm{N}_{0}$} & \multirow{2}{*}{ Nama } & \multicolumn{2}{|c|}{ Penerimaan } & \multicolumn{2}{|c|}{ Biaya Total } & \multicolumn{2}{|c|}{ Pendapatan } & \multirow{2}{*}{$\mathrm{R} / \mathrm{C}$} \\
\hline & & (RppP) & $(\mathrm{Rp} / \mathrm{Bln})$ & (RppP) & $(\mathrm{Rp} / \mathrm{Bln})$ & $(\mathrm{Rp} / \mathrm{PP})$ & $(\mathrm{Rp} / \mathrm{Bln})$ & \\
\hline & Mukti & 310.000 & 9.300 .000 & 258.173 & 7.745 .175 & 51.828 & 1.554 .825 & 1,20 \\
\hline & Markum & 400,000 & 12.000 .000 & 351.365 & 10.540 .950 & 48.635 & 1.459 .050 & 1,14 \\
\hline & Wakiran & 380.000 & 11.400 .000 & 326.502 & 9.795 .065 & 53.498 & 1.604 .935 & 1,16 \\
\hline & Jumlah & 1.090 .000 & 32.700 .000 & 936.040 & 28.081.191 & 153.960 & 4.618 .809 & 3,50 \\
\hline & Rerata & 363.333 & 10.900 .000 & 312.013 & 9.360 .397 & 51.320 & 1.539 .603 & 1,17 \\
\hline
\end{tabular}

Sumber: Olahan Data Primer, 2014.

Berdasarkan hasil perhitungan yang ditampilkan pada tabel 30 diatas, dapat diketahui bahwa total penerimaan yang diperoleh industri tahu dengan kebutuhan kedelai $<500 \mathrm{Kg} / \mathrm{Bulan}$ adalah sebesar Rp 363.333/Proses atau sebesar Rp 10.900.000/Bulan. Total biaya produksi adalah sebesar Rp 312.013/Proses atau sebesar Rp 9.360.397/Bulan sehingga pendapatan yang diperoleh dalam satu kali proses produksi industri tahu dengan kebutuhan kedelai 500-1.000 $\mathrm{Kg} /$ Bulan dalam satu kali proses produksi adalah sebesar Rp 51.320 atau sebesar Rp 1.539.603/Bulan. Nilai R/C rasio industri tahu dengan kebutuhan kedelai 500-1.000 Kg/Bulan 
adalah sebesar 1,17 yang berarti setiap Rp 1 biaya yang dikeluarkan akan menghasilkan penerimaan sebesar Rp 1,17.

Berdasarkan hasil analisis $\mathrm{R} / \mathrm{C}$ rasio pada masing-masing industri tahu pada Tabel 28, 29 dan 30, menunjukkan bahwa nilai $\mathrm{R} / \mathrm{C}$ rasio industri tahu dengan kebutuhan kedelai $>1.000$ $\mathrm{Kg}$ per bulan nilainya adalah 1,23 . Nilai R/C rasio industri tahu dengan kebutuhan kedelai 500$1.000 \mathrm{Kg}$ per bulan nilainya adalah 1,15 . Nilai $\mathrm{R} / \mathrm{C}$ rasio industri tahu dengan kebutuhan kedelai $<500 \mathrm{Kg}$ per bulan nilainya adalah 1,17. Berdasarkan analisa perhitungan $\mathrm{R} / \mathrm{C}$ rasio industri tahu nilainya lebih dari $1(\mathrm{R} / \mathrm{C}>1)$ menunjukkan bahwa usaha pembuatan tahu di Kabupaten OKU Timur menguntungkan. Usaha industri tahu dengan kebutuhan kedelai $>1.000$ $\mathrm{Kg}$ per bulan memeiliki nilai $\mathrm{R} / \mathrm{C}$ rasio terbesar yaitu 1,23 hal ini menunjukan usaha pembuatan tahu dengan kebutuhan kedelai $>1.000 \mathrm{Kg}$ per bulan lebih menguntungkan daripada industri tahu lainnya.

\section{IV.KESIMPULAN DAN SARAN}

\section{A. Kesimpulan}

Berdasarnya hasil penelitian dan analisis yang telah dilakukan, maka dapat ditarik kesimpulan sebagai berikut:

1. Dilihat dari besarnya kebutuhan kedelai dalam satu bulan maka industri tahu di Kabupaten OKU Timur terbagi dalam 3 skala yaitu :

a. $>1000 \mathrm{Kg} /$ bulan, dengan jumlah pengusaha tahu sebanyak 22 pengusaha dari 49 industri tahu.

b. $500-1.000 \mathrm{Kg} / \mathrm{bulan}$ dengan jumlah pengusaha tahu sebanyak 12 pengusaha dari 49 industri tahu.

c. $<500 \mathrm{Kg} /$ bulan dengan jumlah pengusaha tahu sebanyak 15 pengusaha dari 49 industri tahu di Kabupaten OKU Timur.

2. Diversifikasi produk tahu di lokasi penelitian yaitu :

a. Tahu goreng dengan ukuran $4 \times 4 \times 2 \mathrm{~cm}$ dan harga jual $\mathrm{Rp} 200 /$ potong,

b. Tahu goreng dengan ukuran $5 \times 3 \times 2,5 \mathrm{~cm}$ dan harga jual Rp 200/potong,

c. Tahu cina mentah ukuran $6 \times 6 \times 2 \mathrm{~cm}$ dan harga jual $\mathrm{Rp}$ 450/potong dan $\mathrm{Rp}$ 500/potong,

d. Tahu cina mentah ukuran 6 × 5 x 2,5 cm dan harga jual Rp 450/potong, e. Tahu cina mentah ukuran $4 \times 4 \times 2 \mathrm{~cm}$ dan harga jual Rp 450/potong,

f. Tahu cina $1 / 2$ matang ukuran $6 \times 6 \times 2 \mathrm{~cm}$ dan harga jual Rp 500/potong,

g. Tahu cina $1 / 2$ matang ukuran $6 \times 5 \times 2,5 \mathrm{~cm}$ dan harga jual Rp 500/potong,

h. Tahu cina $1 / 2$ matang ukuran $4 \times 4 \times 2 \mathrm{~cm}$ dan harga jual Rp 200/potong.

3. Nilai $\mathrm{R} / \mathrm{C}$ rasio industri tahu dengan kebutuhan kedelai $>1.000 \mathrm{Kg}$ per bulan nilainya adalah 1,23. Nilai $\mathrm{R} / \mathrm{C}$ rasio industri tahu dengan kebutuhan kedelai $500-1.000 \mathrm{Kg}$ per bulan nilainya adalah 1,15 . Nilai $\mathrm{R} / \mathrm{C}$ rasio industri tahu dengan kebutuhan kedelai $<500 \mathrm{Kg}$ per bulan nilainya adalah 1,17. Berdasarkan analisa perhitungan $\mathrm{R} / \mathrm{C}$ rasio industri tahu nilainya lebih dari $1(\mathrm{R} / \mathrm{C}>1)$ menunjukkan bahwa usaha pembuatan tahu di Kabupaten OKU Timur menguntungkan. Usaha industri tahu dengan kebutuhan kedelai > $1.000 \mathrm{Kg}$ per bulan memeiliki nilai $\mathrm{R} / \mathrm{C}$ rasio terbesar yaitu 1,23 hal ini menunjukan usaha pembuatan tahu dengan kebutuhan kedelai $>1.000 \mathrm{Kg}$ per bulan lebih menguntungkan daripada industri tahu lainnya.

\section{B. Saran}

Berdasarkan hasil pembahasan dan kesimpulan yang ada di atas maka saran yang dapat diberikan oleh peneliti adalah:

1. Pengusaha tahu agar meningkatkan keterampilan dalam pembuatan berbagai jenis produk tahu dan olahannya sehingga dapat dihasilkan produk tahu yang lebih bervariasi lagi.

2. Pengusaha tahu agar tetap menjaga kebersihan dan kualitas tahu yang dihasilkan.

3. Kepada Pemerintah agar memberikan bantuan kepada pengusaha tahu baik dalam bentuk pembinaan, modal maupun peralatan dan mesin.

\section{DAFTAR PUSTAKA}

Adisarwanto, T. 2002. Budidaya Dengan Pemupukan Yang Efektif dan Pengoptimalan Peran Bintil akar Kedelai. Penebar Swadaya. Jakarta.

Ambarwati, S. R. R. 1994. Beberapa Aspek Ekonomi pada Industri Tahu dan Tempe, Studi Kasus Industri Tahu dan Tempe di Kecamatan Parung Kabupaten Bogor. Skripsi. Fakultas Pertanian. Institut Pertanian Bogor. Bogor. 
Anonim. 2004. Semakin Banyak Industri Pangan Skala Kecil Gulung Tikar www.kompas.com. (Senin 1 maret 2004). 2010. Kedelai. http://id.wikipedia.org. Diakses 20 Mei 2014.

Badan Pusat Statistik. 2003. National Labour Force Survey. Badan Pusat Statistik. Jakarta.

Badan Pusat Statistik. 2010. Pola Konsumsi Penduduk Di Indonesia Tahun 2010. Jakarta.

Bangun, W. 2007. Teori Ekonomi Mikro. Refika Aditama. Bandung.

Budhisatyarini, 2008. Seminar Nasional Dinamika Pembangunan Pertanian Dan Pedesaan : Tantangan dan Peluang Bagi Peningkatan Kesejahteraan Petani; Nilai Tambah Diversifikasi Hasil Usahatani Bawang Merah Menjadi Bawang Goreng. Pusat Analisis Sosial Ekonomi dan Kebijakan Pertanian Departemen Pertanian : Bogor.

Cahyadi, W. 2007. Kedelai Khasiat dan Teknologi. Bumi Aksara. Jakarta.

Direktorat Gizi Departemen Kesehatan RI. 1981. Daftar Komposisi Bahan Makanan. Bhatara Karya Aksara. Jakarta.

Endang Sutriswati Rahayu, Siti Rahayu, Andika Sidar, Tri Purwadi, dan Saiful Rochdyanto. (2012). Teknologi Proses Produksi Tahu. Yogyakarta: Kanisius.

Hidayat,O.D. 1985. Morfologi Tanaman Kedelai. Hal 73-86. Dalam S.Somaatmadja et al. (Eds). Puslitbangtan. Bogor.

Kartasapoetra, A.G, 1988. Teknik Budidaya Tanaman Pangan di Daerah tropik. Bumi Aksara. Jakarta.

Kurniati. 2008. Kedelai. Indo Book Citra Media. Bogor.

Manurung, M dan R. Rahardja. 2004. Pengantar Ilmu Ekonomi: Mikroekonomi. FE Universitas Indonesia. Jakarta

Muchtadi, D. 2009. Prinsip Teknologi Pengolahan Pangan Sumber Protein. Alfabeta. Bandung.

Pitojo, S. 2003. Benih Kedelai. Kanisius. Yogyakarta.

Prakoso. 2002. Panduan Wirausaha Tempe. Media Presindo.Yogyakarta.
Rayandi. 2008. Panduan Wirausaha Tahu. Media Presindo. Yogyakarta.

Rukmana, 2006. Kacang Tanah dan Kedelai. Kanisius. Yogyakarta.

Sarah, N. 2001. Studi Profil Industri (Studi Kasus Industri Tahu Di Jakarta Timur). Skripsi. Fakultas Teknologi Pertanian. IPB. Bogor.

Sari, Y. P. 2002. Analisis Efisiensi dan Pendapatan Pengrajin Tempe Anggota KOPTI Kotamadya Bogor Propinsi Jawa Barat. Fakultas Pertanian. Institut Pertanian Bogor. Bogor.

SNI 01-3142-1998. Syarat Mutu Tahu. Badan Sertifikasi Nasional. Departemen perdagangan dan Industri. Jakarta.

Rahardja, P dan Manurung, M. 2006. Teori Ekonomi Mikro Suatu Pengantar. Fakultas Ekonomi Universitas Indonesia. Jakarta.

Rangkuti, F. 2009. Analisis SWOT Teknik Membedah Kasus Bisnis. PT. Gramedia Pustaka Utama. Jakarta.

Reksoprayitno, S. 2000. Pengantar Ekonomi Mikro Edisi Melenium. Fakultas Ekonomi Universitas Gadjah Mada. Yogyakarta.

Sjarkowi, 2004. Manajemen Agribisnis. C.V. Baldad Grafiti Press. Palembang.

Sjarkowie, dan Sufri, 2004. Manajemen Agribisnis. CV Baldad Grafiti Press. Palembang.

Sjarkowie, F. 2010. Manajemen Pembangunan Agribisnis. Baldad Grafiti Press. Palembang.

Suratiyah, K. 2002. Ilmu Usahatani. Penebar Swadaya. Bogor.

Suryana, A. 1990. Diversifikasi Pertanian dalam Proses Mempercepat Laju Pembangunan Nasional. Pustaka Sinar Harapan. Jakarta.

Suwardji. 1999. Cara Pembuatan Tahu Konvensional. Liberty. Yogyakarta.

Soekartawi. 2000. Pengantar Agroindustri. . Raja Grafindo Persada. Jakarta.

Sarwono, B dan Saragih, Y.P. 2001. Membuat Aneka Tahu. Penebar Swadaya. Jakarta.

Solahudin, S. 1998. Visi Pembangunan Pertanian. IPB Press. Bogor.

Winarno, F,G. (1993). Pangan Gizi, Teknologi , dan Konsumen. Jakarta: Gramedia .Pustaka Utama. 